\title{
Pengentasan Kemiskinan Berbasis Pemberdayaan Masyarakat Di Kabupaten Pohuwato
}

\author{
Rusni Djafar¹, Umar Sune ${ }^{2}$ \\ Universitas Pohuwato Fakultas Ilmu Sosial Dan Ilmu Politik \\ rusnidjafar1966@gmail.com ${ }^{1}$, umaralmarisi@gmail.com ${ }^{2}$
}

\begin{abstract}
This study aims to explain and analyze empowerment-based poverty alleviation programs through the activities of assistance, facilitation and promotion and determinant factors of success in empowerment-based poverty eradication in Pohuwato District. This research method using qualitative approach, descriptive type to get a complete picture of problem of resource development of apparatus.

The results of the research show that the assistance activities through training, consultation and technical assistance, and similar activities have not been coordinated with other supporting programs, making it difficult for the facilitator task as a program facilitator. Empowering the poor through the provision of facilities, has not been able to improve the capacity of the community. The low capacity and quality of service of government apparatus from the local level to the rural level, so that the provision of facilities does not allow the involvement of the poor. A highly centralized bureaucratic system and a highly authoritarian political system that has been practiced for more than four decades in Indonesia, brings out the weaknesses of the bureaucratic character. Promotion activities in the context of empowering the poor as an activity aimed at developing responsive services, the reality has not been effective in helping facilitate the poor to access various development programs that are beneficial to improving the welfare of the poor by earning productive employment. Activities that require synergies of cooperation between institutions / organizations (Government, Private, NGOs), difficult to realize because the dominance of egoism interests of each stakeholders in addressing every village development program.

It is recommended to optimize training, consultation and technical assistance activities, as well as similar activities coordinated with support programs. Provision of adequate supporting facilities that can empower the poor on an ongoing basis, and streamline promotion to develop responsive services that enable poor people to access programs. Need to pay attention to communication factor, resources, attitude, and bureaucracy structure,so asnot tohinder the smooth implementation of poverty eradication program based on empowerment society.
\end{abstract}

Keywords: Poverty, Empowerment. 


\section{Pendahuluan}

Kemiskinan merupakan masalah yang pada umumnya dihadapi hampir di semua negara-negara berkembang, terutama negara yang padat penduduknya seperti Indonesia. Itu sebabnya, penanggulangan kemiskinan selalu menjadi program rezim yang berkuasa. Laporan Perkembangan Pencapaian Millennium Development Goals (MGD) Indonesia 2007, Menurut Lincolin (2004), pertumbuhan ekonomi yang tinggi gagal untuk mengurangi bahkan menghilangkan besarnya kemiskinan absolut di Negara sedang berkembang. Warga secara individu dan kelompok menginginkan kehidupan yang lebih baik, sejahtera dan bahagia. Masyarakat sejahtera merupakan citacita bersama seluruh rakyat guna terciptanya rasa aman dan makmur. Rasa aman mencerminkan keadaan jiwa yang tidak lagi terganggu oleh ancaman baik secara sosial maupun secara ekonomi. Makmur berarti selalu berada pada tingkatan berkecukupan, tidak lagi merasa kekurangan. Makmur juga berarti bahwa setiap individu memiliki daya dan kemampuan selain untuk memenuhi berbagai kebutuhannya sendiri juga memenuhi harapan atau kebutuhan masyarakat lainnya.
Keberhasilan pembangunan tidak hanya diukur dari kenaikan taraf hidup masyarakat, tetapi terutama sejauhmana pembangunan itu dapat menumbuhkan kemauan dan kemampuan dari suatu masyarakat untuk mandiri. Kemauan masyarakat itu sendiri sebagai kunci untuk menciptakan pembangunan dan melestarikan serta mengembangkan hasil-hasil pembangunan, baik yang berasal dari usaha mereka sendiri maupun yang berasal dari prakarsa yang datang dari luar masyarakat. Dengan memberdayakan masyarakat, berarti dapat meningkatkan kemandirian yaitu, suatu kondisi yang memungkinkan masyarakat mampu membangun dirinya berdasarkan potensi, kebutuhan, aspirasi, dan kewenangan yang ada pada mereka, termasuk kelembagaannya.

$$
\text { Pemerintah mengeluarkan }
$$

Peraturan Presiden Republik Indonesia Nomor 54 Tahun 2005, tentang Percepatan Program Penanggulangan Kemiskinan. Kebijakan itu memunculkan berbagai program antara lain Program Penanggulangan Kemiskinan Perdesaan/Perkotaan (P2KP), Jamkesmas, subsidi dan keluarga harapan, PNPM Mandiri, Kredit Usaha Rakyat (KUR), hingga pengadaan rumah murah sebagai program Menteri Pembangunan Daerah Tertinggal (PDT). 
Kemudian melalui Menteri Koordinator

Bidang Kesejahteraan Rakyat, pada tahun 2007 mengeluarkan Surat Keputusan Nomor 25 Tahun 2007, Tentang Pedoman Umum Program Nasional Pemberdayaan Masyarakat Mandiri (PNPM MANDIRI). Kebijakan Menteri Koordinator Bidang Kesejahteraan Rakyat itu ditindaklanjuti oleh Pemerintah Provinsi hingga Kabupaten/Kota dengan membentuk tim penanggulangan kemiskinan yang beranggotakan lintas sektor. Pada tingkat pusat, dibentuk Tim Nasional Percepatan Penanggulangan Kemiskinan (TNP2K) yang berkedudukan pada Deputi Bidang Kesejahteraan Rakyat dan Penanggulangan Kemiskinan Sekretariat Wakil Presiden RI yang sekaligus sebagai Sekretaris Eksekutif.

Di Kabupaten Pohuwato, dalam 5 (lima) tahun terakhir hingga tahun 2017 persentase jumlah angka kemiskinan masih cukup tinggi dan jauh dari target nasional sebagaimana digambarkan pada tabel berikut ini.

Tabel 1.2.Persentase

Angka

KemiskinanKabupaten

Pohuwato 5 (lima) Tahun terakhir

\begin{tabular}{|c|c|c|}
\hline No. & Tahun & Kabupaten Pohuwato \\
\hline 1. & 2013 & 21,47 \\
\hline
\end{tabular}

\begin{tabular}{|l|l|l|}
\hline 2. & 2014 & 20,69 \\
\hline 3. & 2015 & 22,43 \\
\hline 4. & 2016 & 21,17 \\
\hline 5. & 2017 & 21,27 \\
\hline
\end{tabular}

Sumber Data: Diolah dari data BPS, 2017

Belum tercapainya angka penurunan kemiskinan secara nasional di Kabupaten Pohuwato, menunjukkan belum diterapkannya dengan baik pendekatan pembangunan yang berbasis pada masyarakat sasaran. Programprogram pengentasan kemiskinan dari tingkat nasional hingga daerah selama ini cenderung parsial dan tidak berkelanjutan. Selain itu, peran dunia usaha dan masyarakat pada umumnya belum optimal. Sementara, kerelawanan sosial dalam kehidupan masyarakat yang dapat menjadi sumber pemberdayaan dan pemecahan akar permasalahan kemiskinan juga mulai luntur. Kemiskinan itu sendiri belum dilihat sebagai malapetaka kemanusiaan yang amat tragis. Sebagai fenomena global yang sangat memprihatinkan, kemiskinan harus dituntaskan karena merupakan amanat konstitusi.

Kepedulian dan kesadaran antar sesama warga diharapkan dapat membantu menekan tingkat kemiskinan. Dilingkungan Pemerintahan, menurut Kooiman (1993), perlunya perubahan pola penyelenggaraan pemerintahan dari 
konsep pemerintah (government) menjadi kepemerintahan (governance) sebagai wujud interaksi social politik antara pemerintah dengan masyarakat dalam menghadapi berbagai kontemporer yang demikian kompleks, dinamis, dan beranekaragam.

Dalam konsep administrasi publik, ada dua hal yang menjadi penekanan, yaitu sejauhmanakah atau sebesar apakah kemampuan pemerintah dalam mengatasi setiap persoalan publik yang muncul, dan dalam perspektif legal lebih memiliki arti bahwa ruang lingkup administrasi publik menyangkut aktualisasi hak masyarakat melalui implementasi setiap kebijakan publik yang dibuat, dimana kebijakan publik tersebut adalah produk hukum yang harus dipatuhi oleh warga negara dan pemerintah Shafritz dan Russel, (2005).

Hasil pengamatan di Kabupaten Pohuwato program pengentasan kemiskinan berbasis pemberdayaan masyarakat, belum menggambarkan sinergitas antar Pemerintah Daerah hingga Pemerintah Desa, dengan pihak swasta dan masyarakat sasaran. Perspektif governance yang menjadi acuan penyelenggaraan pemerintahan, belum diterapkan dengan baik terutama dalam mensinergikan tiga pilar yang menjadi kekuatan pemberdayaan masyarakat yaitu, pemerintah, swasta dan masyarakat. Peranan masyarakat cenderung pasif sehingga kemampuan masyarakat miskin untuk membangun diri dan lingkungannya secara mandiri masih sangat rendah. Pemerintah Desa, Badan Permusyawaratan Desa (BPD), Lembaga Pemberdayaan Masyarakat (LPM), dan Lembaga Swadaya Masyarakat (LSM), belum optimal menjalankan fungsinya baik secara kelembagaan maupun secara individu menyatukan kekuatan dalam implementasi program pembangunan yang berorientasi pada pemberdayaan masyarakat. Sebagai lembaga yang diharapkan dapat menjadi wadah aspirasi, mediator dan fasilitator di tingkat akar rumput, belum memiliki kekuatan formal walaupun legalitasnya diakui secara formal.

Tiga aspek dalam program pemberdayaan masyarakat, yakni asistensi, fasilitasi, dan promosi belum diterapkan dengan baik. Aktivitas assistensi dalam hal pelatihan, konsultasi atau asistensi teknis, dan sejenisnya, diberikan secara merata tanpa mengelompokkan kemampuan masyarakat yang dibina. Sedang masyarakat binaan yang masih dikategorikan ke dalam bentuk masyarakat yang berkemampuan rendah, 
model promotion (bantuan pada bidangbidang tertentu yang sangat dibutuhkan), tidak dijadikan sebagai alternatif yang perlu dikembangkan. Selain itu, belum diperhatikannya faktor determinan penentu keberhasilan pengentasan kemiskinan antara lain faktor internal dan faktor eksternal. Faktor internal berkaitan dengn sikap negatif masyarakat miskin, sebagai akibat dari rendahnya kualitas sumberdaya yang dimiliki.

Shafritz dan Russel (2005) dalam bukunya "Introducing Public Administration" memperkenalkan konsep administrasi publik ke dalam empat kategorisasi khusus atau perspektif. Keempat kategori tersebut, perspektif administrasi publik dalam aspek politik, legal, manajerial, jabatan (occupation). Administrasi publik dalam perspektif politik lebih dimaknakan sebagai ukuran telah sejauh manakah atau seberapa besarkah kemampuan pemerintah dalam mengatasi setiap persoalan publik yang muncul.

Perspektif administrasi publik tersebut menimbulkan pergeseran paradigma dalam ilmu administrasi negara sebagai "the larger system of democratic governance", yang memunculkan pemikiran baru yang mengarah kepada perubahan pola penyelenggaraan pemerintahan, yaitu dari pola tradisional atau konvensional menjadi pola baru penyelenggaraan pemerintahan yang melibatkan kolaborasi antara pemerintah, swasta, dan masyarakat, Denhardt and Denhardt, (2003:104).

Salah satu hasil dari tuntutan gerakan reformasi di Indonesia adalah lahirnya Undang-Undang Nomor 22 tahun 1999 yang direvisi lagi dengan Undang-Undang Nomor 32 tahun 2004, tentang Pemerintahan Daerah dan kemudian direvisi lagi dengan UndangUndang Nomor 12 Tahun 2008, dan terakhir dengan Undang-Undang Nomor 23 Tahun 2014. Salah satu makna substansial undang-undang tentang Pemerintahan Daerah tersebut, adalah untuk mempercepat proses pelayanan kepada masyarakat dengan memberikan wewenang yang lebih luas kepada pemerintah daerah.

Pemikiran baru yang kemudian melahirkan pendekatan baru dalam manajemen sektor publik berkaitan dengan pemberian layanan kepada masyarakat oleh Farnham (1993) dalam Denhardt dan Denhardt (2003:403) memunculkan pendekatan yang menamakan dirinya The New Public Management disingkat NPM. Pemikiran baru terhadap layanan masyarakat 
seiring dengan perkembangan kehidupan masyarakat yang semakin hari semakin bertambah, akibat perkembangan ilmu pengetahuan dan teknologi. Manusia sebagai salah satu anggota masyarakat, kebutuhannya pun semakin bertambah. Kebutuhan yang bertambah ini akan membawa persoalan pemenuhannya. Jika sumber-sumber tersedia, kebutuhan itu akan mudah terpenuhi.

Perspektif governance, sudah banyak dijelaskan oleh para pakar. Pertama-tama governance diartikan sebagai "a wide variety of ways to solve common problems inckluding organizatiohal, social, national and international problems", yaitu umumnya merujuk pada pertanyaan tentang bentuk kekuasaan dan otoritas, pola hubungan serta hak dan kewajiban diantara individu yang menghadapi permasalah umum. Konsep "governance" atau "kepemerintahan" dalam istilah Inggris yaitu "the act, fact, manner of governing" berarti, "tindakan, fakta, pola, dan kegiatan atau penyelenggaraan pemerintahan". Berarti, "governance" adalah suatu kegiatan (proses), sebagaimana dikemukakan oleh Kooiman (1993:21) lebih merupakan "... serangkaian proses interaksi sosial politik antara pemerintahan dengan masyarakat dalam berbagai bidang yang berkaitan dengan kepentingan masyarakat dan intervensi pemerintah atas kepentingan-kepentingan tersebut".

Kooiman, (1993). Good governance dalam kesimpulan workshop yang diselenggarakan UNDP sebagai sistem kepemerintahan yang baik adalah partisipasi, yang menyatakan semua institusi governance memiliki suara dalam pengambilan keputusan Dwiyanto,dkk, (2003:4). Oleh karena itu teori governance dan good governance relevan menjelaskan permasalahan kepemimpinan lokal dalam urusan pemerintahan.Pemerintah Indonesia, sejak tahun 2000, telah mengeluarkan Peraturan Pemerintah Nomor 101 tahun 2000, tentang penyelenggaraan pemerintahan yang baik (good governance) sebagai "Kepemerintahan yang mengemban akan dan menerapkan prinsip-prinsip profesionalitas, akuntabilitas, transparansi, pelayanan prima, demokrasi, efisiensi, efektivitas, supremasi hukum dan dapat diterima oleh seluruh masyarakat". Dalam peraturan tersebut unsur-unsur dalam kepemerintahan Governance stakeholders) dikelompokkan menjadi 3 kategori terdiri dari state (Negara), market (pasar/swasta), dan civil society (masyarakat). 
Ketiga unsur tersebut dijelaskan sebagai

berikut:

Negara/Pemerintahan.

Konsepsi

kepemerintahan pada dasarnya adalah kegiatan kenegaraan, tetapi lebih jauh dari itu melibatkan pula sektor swasta dan kelembagaan masyarakat madani; (2) Market (pasar/swasta). Pelaku sektor swasta mencakup perusahaan swasta yang aktif dalam interaksi dalam sistem pasar, seperti: industri pengolahan perdagangan, perbankan, dan koperasi, termasuk kegiatan sektor informal; dan (3) Masyarakat Madani. Kelompok masyarakat dalam konteks kenegaraan pada dasarnya berada diantara atau di tengah-tengah antara pemerintah dan perseorangan, yang mencakup baik perseorangan maupun kelompok masyarakat yang berinteraksi secara sosial, politik dan ekonomi.

Proses pembangunan menurut Rahmaddin (2009:2) sebenarnya adalah merupakan suatu perubahan sosial budaya. Pembangunan supaya menjadi suatu proses yang dapat bergerak maju atas kekuatan sendiri tergantung kepada manusia dan struktur sosialnya. Pembangunan tergantung dari suatu innerwill, proses emansipasi diri. Perubahan-perubahan dalam masyarakat yang bersifat menyeluruh tersebut, dapat dikembangkan secara sadar oleh pemerintah, yang sebaiknya pula mewakili kekuatan-kekuatan pembaharuan di dalam masyarakat. Pembangunan masyarakat Indonesia yang di cita-citakan sebagaimana tujuan pembentukan Negara Kesatuan Republik Indonesia yang tercantum dalam Pembukaan UUD 1945, yaitu untuk (1) Melindungi segenap bangsa dan seluruh tumpah darah Indonesia; (2) Memajukan kesejahteraan umum; (3) Mencerdaskan kehidupan bangsa; dan (4) Ikut melaksanakan ketertiban dunia. Dari keempat tujuan ini, tiga di antaranya secara eksplisit menyatakan kualitas kehidupan, yaitu butir pertama, kedua, dan ketiga (kehidupan masyarakat yang terlindungi, sejahtera, dan cerdas). Sedangkan untuk distribusi dan pemerataan kualitas hidup tersebut dirumuskan dalam Sila Kelima Pancasila yaitu mewujudkan keadilan sosial bagi seluruh rakyat Indonesia. Intinya adalah keterlindungan, kesejahteraan, dan kecerdasan masyarakat, haruslah terdistribusi secara adil.

Upaya pengentasan kemiskinan sangat erat berhubungan dengan kebijakan pembangunan masyarakat. Menurut Kuncoro, dkk (2004:226-227), pembangunan merupakan proses yang dilakukan dengan sengaja untuk mencapai kondisi yang lebih baik. Ada 
dua paradigma pembangunan yang dilakukan selama ini, yaitu paradigma top-down dan pendekatan bottom-up. Paradigma top-down merupakan bentuk blue-print strategy (cetak biru) sebagai paradigma pembangunan yang bersumber pada pemerintah, dengan demikian masyarakat hanyalah sebagai sasaran atau obyek pembangunan saja. Sedangkan paradigma pembangunan bottom-up merupakan paradigma pembangunan yang memposisikan masyarakat sebagai subyek pembangnan (people center development) sehingga terlibat dalam proses perencanaan sampai pada pelaksanaan dan evaluasi.

Pentingnya asistensi dalam program pemberdayaan masyarakat menurut Kartasasmita (2004), karena kemiskinan antara lain disebabkan oleh (a) faktor rendahnya taraf pendidikan. Taraf pendidikan yang rendah mengakibatkan kemampuan pengembangan diri terbatas dan menyebabkan sempitnya kerja yang dapat dimasuki; (b) Rendahnya derajat kesehatan. Taraf kesehatan dan gizi yang rendah menyebabkan rendahnya daya tahan fisik, daya pikir, dan rendahnya prakarsa; (c) Terbatasnya lapangan kerja. Keadaan kemiskinan karena kondisi pendidikan diperberat oleh terbatasnya lapangan pekerjaan. Selama ada lapangan kerja atau kegiatan usaha, selama itu pula ada harapan untuk memutuskan lingkaran kemiskinan; dan (d) Kondisi keterisolasian. Banyak penduduk miskin, secara ekonomi tidak berdaya karena terpencil dan terisolasi. Mereka hidup terpencil sehingga sulit atau tidak dapat terjangkau oleh pelayanan pendidikan, kesehatan, dan gerak kemajuan yang dinikmati masyarakat lainnya.

Dalam kegiatan fasilitasi dan promosi sebagai suatu kegiatan pemberdayaan yang memugkinkan masyarakat miskin mudah mengakses berbagai program-program pembangunan untuk peningkatan kesejahteraan. Karena menurut Mafruhah (2009), kemiskinan seseorang dapat disebabkan oleh: Kegagalan kepemilikan, terutama tanah dan modal, terbatasnya kesediaan lahan kebutuhan dasar, sarana dan prasarana, kebijakan pembangunan yang bias perkotaan dan bias sektor, adanya perbedaan kesempatan di antara anggota masyarakat dan sistem yang kurang mendukung, adanya perbedaan sumber daya manusia dan perbedaan antara sektor ekonomi (ekonomi tradisional versus ekonomi modern), rendahnya produktivitas dan tingkat pembentukan modal dalam masyarakat, budaya hidup 
yang dikaitkan dengan kemampuan seseorang mengelola sumber daya alam dan lingkungannya, tidak adanya tata pemerintahan yang bersih dan baik, pengelolaan sumber daya alam yang berlebihan dan tidak berwawasan lingkungan.

Menjadikan rumah tangga miskin merupakan suatu unit yang proaktif dan oleh kelompok yang dibina, maka bentuk lazim dilakukan adalah dengan assistance (misalnya dalam bentuk pelatihan, konsultasi atau asistensi teknis, dan sejenisnya). Apabila masyarakat binaan masih dikategorikan produktif, menurut Jamasy (2004:58) "Setidaknya ada tiga aspek yang lazim dikenal yakni asistensi, fasilitasi, dan promosi. Apabila sejumlah kemampuan sudah dimiliki ke dalam bentuk masyarakat yang berkemampuan rendah, maka alternatif yang perlu dikembangkan adalah model promotion (bantuan pada bidang-bidang tertentu sangat dibutuhkan)".Dalam penelitian ini, pengentasan kemiskinan berbasis pemberdayaan difokuskan pada aktivitas asistensi, fasilitasi, dan promosi. Ketiga aktivitas itu harus dilaksanakan secara berkelanjutan hingga masyarakat miskin memiliki kekuatan dan akses terhadap sumber daya untuk mencari nafkah.
Jamasy (2004:41-42) menegaskan bahwa kerangka berpikir dalam proses pemberdayaan setidaknya mengandung tiga tujuan penting yang terdiri dari :

Pertama, menciptakan suasana atau iklim yang memungkinkan potensi masyarakat berkembang;

Kedua, memperkuat potensi atau daya yang dimiliki masyarakat atau kelompok yang akan diberdayakan, misalnya melalui peningkatan taraf pendidikan, peningkatan derajat kesehatan, serta peningkatan akses terhadap sumber-sumber kemajuan; dan

Ketiga, upaya melindungi (mencegah) terjadinya persaingan yang tidak seimbang, menciptakan keadilan, serta menciptakan kebersamaan dan kemitraan antara yang sudah maju dengan yang belum berkembang.

Dengan demikian, pemberdayaan bukan hanya sekedar pendekatan, melainkan menjadi faktor utama program pembangunan dalam kaitannya dengan pengentasan dan penanggulangan kemiskinan. Hakikat pemberdayaan terletak pada berlangsungnya proses yang utuh, proses yang mengutamakan aksi-refleksi, proses 
yang konkrit dan bukan hanya sebagai cita-cita.

Pengentasan kemiskinan berbasis pemberdayaan sebagai suatu kebijakan publik yang telah diputuskan oleh Pemerintah melalui peraturan perundang-undang antara lain melalui Peraturan Presiden Republik Indonesia Nomor 54 Tahun 2005, tentang Percepatan Program Penanggulangan Kemiskinan dan ditindaklanjuti dengan Surat Keputusan Menteri Koordinator Bidang Kesejahteraan Rakyat Nomor 25 Tahun 2007, Tentang Pedoman Umum Program Nasional Pemberdayaan Masyarakat Mandiri (PNPM MANDIRI).

Sebagai suatu kebijakan Pemerintah (publik), secara teoritis keberhasilan pengentasan kemiskinan menurut Edward III, dalam Subarsono, (2005:90), ditentukan oleh faktor-faktor sebagai berikut: (a) komunikasi, (b) sumber daya, (c) disposisi (sikap), (d) stuktur birokrasi. Keempat faktor tersebut saling berhubungan satu sama lain sebagaimana diuraikan sebagai berikut.

Komunikasi; Komunikasi diperlukan untuk mentransmisikan tujuan dan sasaran kebijakan program pengentasan kemiskinan kepada kelompok atau rumah tangga sasaran (RTS) dalam hal ini warga miskin guna mengurangi distorsi. Tujuan dan sasaran program yang tidak jelas bahkan tidak diketahui sama sekali oleh kelompok sasaran, kemungkinan akan terjadi resistensi dari kelompok sasaran. Demikian pula dengan program pengentasan kemiskinan berbasis pemberdayaan, tujuan program perlu ditransmisikan (ditularkan/disebarkan) kepada seluruh warga miskin yang menjadi sasaran program.

Sumber daya; walaupun isi kebijakan program pengentasan kemiskinan sudah dikomunikasikan secara jelas dan konsisten, jika implementor kekurangan sumber daya (manusia yg memiliki kompetensi dan finansial) maka implementasinya tidak akan efektif. Persyaratan kompetensi dan finansial (anggaran) dalam melaksanakan prorgam pengentasan kemiskinan, merupakan hal mutlak mengingat sasaran program adalah keluarga miskin yang ada di perdesaan memiliki tingkat kerentanan dan ketidak berdayaan baik dari segi fisik maupun non fisik. Apa yang diaspirasikan oleh warga miskin, diharapkan dapat dituangkan dalam bentuk rencana program yang konkrit dapat meningkatkan kedudukan, peran, dan kemandirian serta ketahanan mental dan spiritual. 
Desposisi; desposisi atau sikap sebagai watak atau karakteristik yang dimiliki implementor (aparat), seperti komitmen, kejujuran, sifat demokratis. Jika implementor memiliki sikap yang baik, maka dia akan menjalankan kebijakan dengan baik, sebaliknya jika implementor memiliki sikap yang berbeda maka proses implementasi tidak efektif. Meningkatkan kedudukan, peran, dan kemandirian serta ketahanan mental dan spiritual masyarakat miskin, membutuhkan komitmen, kejujuran, sifat demokratis para implementor mengingat, peran warga miskin di perdesaan memiliki potensi reproduktif dan produktif. Jika implementor tidak memiliki komitmen, kejujuran, dan sifat demokratis, potensi warga miskin tidak akan maksimal diwujudkan.

Struktur birokrasi; aspek penting dalam struktur organisasi adalah adanya prosedur operasi yang standar (standard operating procedures/SOP), sebagai pedoman bagi setiap implementor dalam bertindak bagi terlaksananya program pengentasan kemiskinan. Struktur organisasi yang terlalu panjang akan cenderung melunakkan pengawasan dan menimbulkan red-tipe, yakni prosedur birokrasi yang rumit dan kompleks. Pada gilirannya menimbulkan aktivitas organisasi tidak fleksibel. Struktur organisasi yang dibutuhkan dalam implementasi program pengentasan kemiskinan berbasis pemberdayaan adalah struktur yang mampu mengkoordasikan berbagai kegiatan yang melibatkan lintas bidang pembangunan.

Berdasarkan pendapat Edward III tersebut, menurut penulis keberhasilan pengentasan kemiskinan berbasis pemberdayaan di Kabupaten Pohuwato, ditentukan oleh keempat faktor sebagai determinannya. Masih dominannya intervensi Pemerintah dan aparat dalam setiap implementasi kebijakan program, maka kewajiban Pemerintah untuk dapat mengkomunikasikan program, menyediakan sumber daya baik manusia maupun non manusia, dengan sikap (disposisi), dan stuktur birokrasi yang adaptif terhadap aspirasi masyarakat. Pengentasan kemiskinan berbasis pemberdayaan membutuhkan keterlibatan berbagai pihak mensyaratkan perlunya unsur utama governance, yaitu: akuntabilitas (accountability), transparansi (transparency) keterbukaan (opennes) dan aturan hukum (rule of law) ditambah dengan kompetensi manajemen (management competence) dan hak-hak azasi manusia (human right), Bhatta, (1996). 


\section{METODE PENELITIAN}

Penelitian ini menggunakan pendekatan studi kasus untuk mengungkap makna tentang kasus pengentasan kemiskinan berbasis pemberdayaan di Kabupaten Pohuwato. Melalui pendekatan ini, programprogram Pemerintah yang ditujukan untuk mengentaskan kemiskinan dapat diteliti secara menyeluruh, utuh dan mendalam sebagai salah satu kasus dalam memberdayakan masyarakat. Dengan kata lain, kasus yang diteliti dipandang sebagai obyek yang berbeda dengan obyek penelitian pada umumnya, Stake (1995), khususnya dalam setiap program pemberdayaan.

Adapun jenis penelitian yang digunakan adalah kualitatif, peneliti melakukan kajian secara rinci, mendalam, menyeluruh terhadap aspek program yang berkaitan dengan pengentasan kemiskinan dengan memadukan teknik pengamatan, wawancara mendalam, dan analisis dokumen (multi-metode). Dalam pelaksanaan penelitian, peneliti berusaha membatasi waktu dan tempat, serta kasus yang dipelajari sebagai suatu keseluruhan yang terintegrasi pada program-program pengentasan kemiskinan yang berbasis pemberdayaan.
Lokasi penelitian di Kabupaten Pohuwato, dengan pertimbangan bahwa : Kabupaten Pohuwato dipilih karena penulis sudah mengenal tempat yang menjadi objek penelitian serta mudah di jangkau, serta menarik untuk diteliti sebab memiliki persentasi angka kemiskinan di atas target nasional yakni 21,17 persen tahun 2017.

Untuk memudahkan peneliti dalam pengambilan data penelitian ini, maka peneliti menggunakan sumber data untuk mengungkapkan fakta dibalik kasus program pengentasan kemiskinan antara lain yang berasal dari data primer dan data sekunder. Hal itu dilakukan agar peneliti memperoleh keragaman sumber data untuk mencapai validitas dan realibilitas data, sehingga hasil penelitian dapat diyakini kebenarannya. Fakta dicapai melalui pengkajian keterhubungan bukti-bukti dari beberapa sumber data antara lain melalui dokumen, rekaman, observasi, wawancara terbuka, wawancara terfokus, wawancara terstruktur dan survey lapangan. data antara lain melalui dokumen, rekaman, observasi, wawancara terbuka, wawancara terfokus, wawancara terstruktur dan survey lapangan. 
Adapun partisipan sebagai informan yang telah memberikan informasi terdiri dari:

Pemerintah Daerah Kabupaten Pohuwato (TKPKD), Kepala-kepala OPD yang terkait dengan masalah penelitian, Para Camat di wilayah Kabupaten Pohuwato Pemerintah Desa dan Aparatnya, Pengurus Badan Permusyawaratan Desa (BPD), Tokoh masyarakat, Masyarakat Sasaran. Dalam penelitian, peneliti menggunakan pendekatan kualitatif, sehingga yang menjadi instrumen penelitian adalah peneliti sendiri. Peneliti sebagai instrument memperoleh data yang valid dan reliabel. peneliti menggunakan teknik pengumpulan data melalui kegiatan Observasi, wawancara , dokumentasi dari fenomena penelitian.

Menurut Sugiyono (2012:203) Teknik pengumpulan data dengan observasi digunakan bila, penelitian berkenaan dengan perilaku manusia, proses kerja, gejala-gejala alam dan bila responden yang diamati tidak terlalu banyak.

Untuk menganalisis data yang diperoleh dari hasil penelitian ini, penulis merujuk pada pendapat Miles dan Huberman (2014:32), terdiri dari komponen utama : 1) Collectioan Data (Pengumpulan Data) 2).Condensation
Data (Konensasi Data) 3). Display Data (Penyajian Data), dan 4). Conclution Drawing (Penarikan Kesimpulan).

1) Collection Data (Pengumpulan Data)

Pada tahapan pengumpulan penelitian, data diperoleh melalui metode wawancara mendalam kepada informan terkait dengan permasalahan bagaimana pengentasan kemiskinan melalui pemberdayaan masyarakat melalui kegiatan asistensi, fasilitasi dan promosi, kemudian hasil wawancara tersebut dipilih sesuai indikator dengan maksud untuk mempermudah dalam menganalisis.

2) Condensation Data (Kondensasi

Data)

Kondensasi data dilakukan secara terus-menerus selama proses penelitian berlangsung, dimana pada tahapan ini, data laporan hasil lapangan baik berupa data hasil pengamatan, data wawancara dengan informan maupun data sekunder berupa dokumen tentang programprogram pemberdayaan masyarakat. Pada Kondensasi data ini peneliti melakukan pengelompokan data dan data yang tidak terpakai di reduksi agar memudahkan dalam penyajian data.

3) Display Data (Penyajian data)

Pada proses ini data dikumpulkan berdasarkan fokus masalah, kemudian disederhanakan dan dikonstruksikan 
sedemikan rupa guna melengkapi interpretasi data. Panyajian data dilakukan dalam bentuk tabel dan grafik. Hal ini dilakukan untuk mempermudah penafsiran pengembangan dan memudahkan peneliti melakukan analisis terhadap temuan penelitian. Penyajian data dalam bentuk interpretasi hasil penelitian yang dikondensasikan untuk melakukan pembahasan sesuai hasil penelitian dan melakukan penarikan kesimpulan.

\section{4) Drawing Conclution (Penarikan} Kesimpulan)

Setelah proses penyajian data, maka selanjutnya adalah penarikan kesimpulan. Untuk mancari makna terhadap data yang dikumpulkan melalui berbagai informasi yang terkait dengan fokus masalah. Pada awalnya dilakukan penarikan kesimpulan sementara dan kemudian diverifikasi masing-masing data yang ada, dan jika perlu membuang data yang dianggap tidak terlalu penting, dan berdasarkan data-data yang ada selanjutnya dilakukan penarikan kesimpulan akhir yang menjawab permasalahan penelitian.

\section{HASIL PENELITIAN DAN PEMBAHASAN}

Penelitian ini memfokuskan permasalahan pengentasan kemiskinan berbasis pemberdayaan melalui kegiatan asistensi, fasilitasi, dan promosi secara berkelanjutan.

Pendekatan

pemberdayaan dalam pengentasan kemiskinan ini mensyaratkan sinergitas para pemangku kepentingan, khususnya peran Pemerintah Daerah dan masyarakat sasaran. Berdasarkan pengumpulan data baik data primer maupun data sekunder, hasil penelitian diuraikan sebagai berikut.

Hasil penelitian ini pula menunjukkan bahwa kegiatan asistensi melalui pelatihan dan ketrampilan kepada masyarakat sasaran sebagai penerima bantuan bertujuan agar masyarakat sasaran memiliki kemampuan dalam mengelolah bantuan sehingga masyarakat menjadikan hidup mandiri. Ditemukan pula bahwa belum dilibatkannya secara utuh masyarakat miskin sebagai sasaran program mulai proses perencanaan, pelaksanaan hingga evaluasi, sehingga penurunan angka kemiskinan melambat. Pada dasarnya, program pengentasan kemiskinan melalui pemberdayaan merupakan strategi yang memanusiakan manusia karena menggunakan pendekatan proses dimana pelibatan masyarakat dalam pembangunan lebih mengarah kepada bentuk partisipasi, bukan dalam bentuk mobilisasi. Menurut Soetomo (2006), "Partisipasi masyarakat dalam perumusan program membuat 
masyarakat tidak semata-mata

berkedudukan sebagai konsumen program, tetapi juga sebagai produsen karena telah ikut serta terlibat dalam proses pembuatan dan perumusannya, sehingga masyarakat merasa ikut memiliki program tersebut dan mempunyai tanggung jawab bagi keberhasilannya serta memiliki motivasi yang lebih bagi partisipasi pada tahaptahap berikutnya". Dengan strategi itu, terjadi penguatan modal sosial di masyarakat (kelompok) sehingga akan mudah mengarahkan dan mengatur masyarakat serta mudah mentransfer pengetahuan (knowledge) kepada masyarakat dengan menanamkan kepercayaan (trusts), patuh aturan (role), dan pembentukan jaringan (networking).

Dapat dianalisis bahwa kurangnya motivasi kerja oleh pemerintah kepada masyarakat mengakibatkan berkurangnya pendapatan keluarga dan juga karena kurangnya kemauan pemerintah dalam memberikan motivasi kepada masyarakat berupa dukungan dalam memberikan perhatian penuh dalam pengembangan usaha sebagai dukungan terhadap kemampuan masyarakat agar menjadi masyarakat mandiri atas produktifitas mereka sendiri. Fungsi fasilitator sebagai konsultan pendamping program sekaligus konsultan teknis kurang maksimal. Selaras dengan pendapat Mariana, dkk, (2010:3), bahwa Pemerintah memegang peran penting sebagai salah satu aktor strategis untuk mewujudkan kesejahteraan masyarakat, karena pemerintah memiliki kekuasaan sebagai agen pembangunan dan pembaharuan. Sekalipun tingkat sosial dan ekonomi suatu masyarakat telah meningkat, peran pemerintah tetap diperlukan untuk melaksanakan fungsi regulasi, alokasi, distribusi, pelayanan, dan pemberdayaan masyarakat. Fungsifungsi ini harus dilaksanakan oleh pemerintah agar tercapai keadilan dan pemerataan dalam masyarakat.

Pemberdayaan masyarakat yang dilakukan pemerintah belum maksimal menjadikan kemandirian dan ke "daya"an dalam meningkatkan harkat dan martabat lapisan masyarakat miskin. Ketidakmampuan melepaskan diri dari perangkap kemiskinan dan keterbelakangan, karena selama ini menurut Karsidi (2002), Pemberdayaan belum dilakukan dengan cara (1) Belajar dari masyarakat; (2) Memaksimalkan pendamping sebagai fasilitator, masyarakat sebagai pelaku; (3) Saling belajar dan saling berbagi pengalaman. Pemberdayaan belum maksimal memampukan dan memandirikan 
masyarakat dan belum efektif menerapkan prinsip-prinsip dasar pendampingan masyarakat.

Hasil penelitian tentang Penyediaan fasilitas infrastruktur sarana dan prasarana yang dapat meningkatkan kapasitas masyarakat tersebut, perlu ditunjang dengan fasilitas non-tunai berupa, Jaminan Kesehatan Nasional (JKN), Kartu Keluarga Sejahtera (KKS), Program Indonesia Pintar (PIP), Program Keluarga Harapan (PKH), dan penyediaan Beras Untuk Keluarga Miskin (Raskin), namun masyarakat miskin belum juga memiliki "daya" dalam memperbaiki kualitas hidupnya. Fasilitas-fasilitas yang disediakan itu belum mengarah pada peningkatan produktivitas individu masyarakat miskin. Penyediaan infrastrukur desa yang dibiayai dari dana APBD pun sulit diakses oleh masyarakat, karena umumnya program-program tersebut dilaksanakan dalam bentuk proyek yang dipihak ketigakan (Dikontrakan kepada pihak swasta), termasuk program perbaikan kawasan kumuh yang tersebar di desa-desa.

Pemberdayaan masyarakat miskin melalui kegiatan promosi, adalah memberdayakan masyarakat miskin dengan cara bekerjasama dan bersinergi dengan lembaga/organisasi (Pemerintah,
Swasta, LSM) mengembangkan layanan yang responsif dalam usaha menciptakan kesadaran, memberitahukan, membujuk dan mempengaruhi masyarakat miskin agar mampu memenuhi kebutuhannya pada bidang-bidang tertentu yang memungkinkan dirinya mandiri. Kerjasama yang dimaksud, membutuhkan inisiasi pemimpin daerah mulai tingkat atas (Bupati) hingga tingkat bawah (Kepala Desa). Pemimpin di tingkat bawah (Camat dan Kepala Desa), sebagai vioner dalam memotivasi dan menggerakkan masyarakat desa, harus ditunjang oleh kepemimpinan ditingkat atas. Membangun kerjasama yang melibatkan para stakeholders membutuhkan power (kekuasaan) dan kemampuan dalam pengambilan keputusan terutama dalam pengalokasian anggaran. Pengentasan kemiskinan adalah masalah yang rumit (meta problem), yang memerlukan kebijakan yang tepat (Dunn, 2003:227), guna memperbaiki ketidakadilan distribusi, keterbatasan akses dan meningkatkan kemampuan orang miskin agar dapat terlibat dalam aktivitas ekonomi.

Berdasarkan hasil penelitian bahwa Pemerintah Kabupaten telah berusaha melalui layanan kerjasama dengan lembaga-lembaga yang berkepentingan 
antara lain lembaga pemberdayaan masyarakat (LPM), Karang Taruna LSM bahkan lembaga keuangan mikro antara lain perbankan, dan lembaga lainnya yang terkait. Hal ini dilakukan dengan tujuan agar program pemberdayaan masyarakat dalam penaggulangan kemiskinan dapat tercapai, namun masih perlu di optimalkan.

Fungsi Tim Koordinasi

Penanggulangan Kemiskinan Daerah (TKPKD) Kabupaten Pohuwato, dalam program pengentasan kemiskinan terbatas pada memberi saran dan anjuran kepada setiap pimpinan SKPD dari tingkat Kabupaten hingga Kecamatan, agar dapat bersinergi melalui program-program yang bertujuan mengentaskan kemiskinan, dikoordinasikan dan disenergikan antar satu dengan lainnya demikian juga lembaga-lembaga sebagai penunjang dalam rangka peningkatan modal usaha masyarakat. Dalam setiap kegiatan progam baik ditingkat Kabupaten (SKPDSKPD), tingkat Kecamatan hingga di tingkat desa, Bupati maupun Wakil Bupati selalu menekankan bahwa keberhasilan suatu program dapat dicapai melalui fungsi koordinasi, sinkronisasi dan kerjasama. Namun, dalam praktiknya ketiga konsep tersebut sulit diwujudkan karena hambatan administrasi dan

pertanggungjawabannya.

Ada

kekhawatiran dikalangan pimpinan SKPD mengalami hambatan dalam pencapaian target, jika harus berkoordinasi, bersinergi dan bekerjasama dengan SKPD lain karena adanya perbedaan jumlah dan jenis program maupun anggaran.

Dapat dijelaskan pula bahwa usaha yang telah diusahakan oleh pemerintah telah terlihat dengan jelas, namum perlu di ketahui bahwa sinergitas program membutuhkan komunikasi serta koordinasi bahkan peran dari aktor dengan sungguh-sungguh dengan demikian keinginan untuk memberdayakan masyarakat agar keluar dari permasalahan kemiskinan akan terwujud seperti harapan. Rumah tangga miskin dapat diberdayakan untuk ke luar dari kondisi kemiskinan bila anggota rumah tangga yang bersangkutan memiliki sikap yang kuat untuk ke luar dari kondisi kemiskinan itu serta perilaku yang menunjukkan perwujudan sikap tersebut. Di Daerah Kabupaten Pohuwato, untuk menanggulangi kemiskinan yang jumlahnya dari tahun ke tahun tidak berkurang secara signifikan sangat membutuhkan usaha yang cukup besar. 
Menurut Dunn (2003: 227) kebijakan pengentasan kemiskinan adalah masalah yang rumit, yang memerlukan kebijakan yang tepat guna memperbaiki ketidakadilan distribusi, keterbatasan akses dan meningkatkan kemampuan orang miskin agar dapat terlibat dalam aktivitas ekonomi. Untuk menanggulangi kemiskinan dibutuhkan pelibatan berbagai pihak melalui program-program pengentasan kemiskinan, mulai dari yang sifatnya bantuan sosial sampai yang bersifat pemberdayaan.

Berbagai upaya untuk mengatasi kemiskinan telah dilaksanakan bukan hanya oleh Pemerintah Pusat dan Daerah, bahkan oleh lembaga-lembaga sosial masyarakat (di antaranya lembaga zakat) maupun perusahaan melalui program Corporate Social Responsibility (CSR). Namun dikarenakan belum adanya sistem pengentasan kemiskinan yang terintegrasi, telah mengakibatkan pelaksanaan program-program, khususnya program pemerintah cenderung tidak koordinatif, terjadi tumpang tindih (overlapping) antar program, terjadi ego sektoral, tidak terpadu, tidak merata, tidak menyeluruh baik dalam aturan, acuan, kriteria penerima manfaat, maupun pengelolaannya.
Pelibatan masyarakat dalam program pemberdayaan masyarakat oleh pemerintah belum memperoleh respon yang positif dari masyarakat karena masih ada pemikiran masyarakat bahwa tugas pemerintah dalam program ini sangat besar sehingga jika dinilai keberhasilan program tersebut dinilai kurang optimal. Diharapkan Lembaga kemasyarakatan desa yang merukan mitra kerja dari pemerintah desa antara lain Badan Permusyawaratan Desa (BPD) dan Lembaga Pemberdayaan Masyarakat (LPM), sebagai mediator dalam mengembangkan layanan masyarakat di tingkat desa, menampung dan menyalurkan aspirasi, dinilai belum mampu mengakselerasikan kepentingan masyarakat miskin.

\section{Faktor Determinan Keberhasilan}

\section{Pengentasan Kemiskinan Berbasis}

\section{Pemberdayaan}

Pemberdayaan merupakan upaya untuk meningkatkan potensi diri kelompok masyarakat miskin sehingga mereka memiliki kekuatan dan selanjutnya memiliki posisi tawar di lingkup masyarakat yang lebih luas. Diketahui akar permasalahan kemiskinan adalah kondisi masyarakat yang belum berdaya dalam hal perilaku, sikap, cara pandang masyarakat yang tidak bertumpu pada nilai-nilai universal 
kemanusiaan (jujur, dapat dipercaya, ikhlas, dll), dan pada prinsip-prinsip universal kemasyarakatan (transparansi, akuntabilitas, partisipasi, demokratisasi). Sebagai suatu kebijakan, secara teoritis keberhasilan pengentasan kemiskinan berbasis pemberdayaan pada tataran implementasi, ditentukan oleh faktorfaktor determinan, adalah sebagai berikut:

\section{Faktor Komunikasi}

Kemampuan komunikasi personal aparat di tingkat bawah dalam menjalankan tugas dan fungsi membantu Pemerintah Daerah Kabupaten Pohuwato, belum optimal terutama dalam menyampaikan informasi dan pesan-pesan yang tertuang dalam setiap amanah kebijakan pembangunan. Apa yang menjadi pesan dalam kebijakan program pemberdayaan termasuk berbagai bentuk kegiatannya, membutuhkan kapasitas komunikasi aparatur pemerintah dalam menyampaikan informasi, ide (gagasan), pendapat atau saran kepada masyarakat sasaran, agar terbangun kerjasama yang efektif dan efisien. Hal itu dikemukakan oleh Lasswell (dalam Effendi, 2001), bahwa komunikasi sebagai proses penyampaian informasi, ide (gagasan), pendapat/saran-saran dan perasaan kepada orang lain, guna mewujudkan kerjasamaa yang efektif dan efisien bagi pencapaian tujuan bersama.

Menurut Mulyana (2002:112), bahwa komunikasi bertujuan untuk memberikan pengaruh kepada seluruh anggota organisasi, agar mereka baik secara perseorangan atau secara bersama memahami misi dan tanggung jawab dalam rangka mencapai tujuan organisasi.

Belum maksimalnya komunikasi aparat kepada masyarakat merupakan gambaran, bahwa program-program pembangunan yang dapat mempercepat peningkatan kesejahteraannya, belum memenuhi harapan warga masyarakat. Walaupun aparat dalam berkomunikasi dengan masyarakat menggunakan bahasa daerah (Gorontalo), terutama dalam menyampaikan informasi dan pesan. Faktor komunikasi sangat berperan dalam setiap pekerjaan individu organisasi, dan mempunyai dampak signifikan terhadap keefektifan organisasi secara keseluruhan sebagaimana dikemukakan oleh Silalahi (2003), bahwa komunikasi mempunyai sejumlah pengaruh baik terhadap tipe sasaran, tugas keorganisasian dan maintenance.

\section{Faktor Sumber Daya}

Berdasarkan hasil penelitian bahwa sumber daya aparatur pemerintah di 
tingkat pelaksana sebagian belum dapat memberikan pelayanan secara optimal terutama menyangkut kesiapannya sebagai pelayan masyarakat, baik dilihat dari aspek pendidikan, keterampilan dan keahlian serta kesejahteraannya. Hal ini menunjukkan kurangnya kualitas layanan yang diberikan sesuai dengan harapan masyarakat. Walaupun pemerintah telah berusaha membina melalui usaha meningkatkan kapasitas aparatur termasuk tenaga hornorer daerah. Aparat sebagai pelaksana organisasi pemerintahan sampai di tingkat desa merupakan faktor penentu dalam pencapaian tujuan organisasi terutama dalam program pemberdayaan masyarakat

Aparat ditingkat pelaksana sebagai anggota organisasi menurut Wijadi (2004:23), perlu diberdayakan dan digerakkan secara efektif dan efisien. Persyaratan dalam menjalankan tugas tersebut, menurut Siagian (2002:11), harus memiliki kemampuan sebagai sumber daya manusia organisasi, dengan cara: (1) mengakui harkat dan martabat manusia, seperti harga diri, daya nalar, kebebasan memilih, akal, perasaan, dan berbagai kebutuhan yang sangat beraneka ragam. (2) manusia mempunyai hak-hak yang bersifat asasi dan tidak ada manusia lain, termasuk manajemen yang dibenarkan untuk melanggar hak-hak tersebut".

Berdasarkan uraian di atas, faktor sumber daya aparat di tingkat lokal sangat penting membantu keberhasilan pelaksanaan program-program pembangunan yang bertujuan mengentaskan kemiskinan berbasis pemberdayaan. Kurang berperannya aparat di tingkat bawah, mengakibatkan program pengentasan kemiskinan berbasis pemberdayaaan belum sesuai harapan. Berbagai upaya Pemerintah dan Pemerintah Daerah mengentaskan kemiskinan, tidak ada artinya tanpa dukungan dan peran aktif aparat di tingkat bawah.

\section{Faktor Sikap Pelaksana}

Minimnya peran aparat di tingkat bawah dalam setiap pelaksanaan program pemberdayaan, sehingga pengalaman dalam mengidentifikasi dan memobilisasi aspirasi masyarakat kurang maksimal. Padahal sebagai aparat yang berhadapan langsung dengan masyarakat, aparat di tingkat kecamatan dan desa perlu diberdayakan dalam hal pengetahuan, keterampilan dan kemampuan di berbagai bidang menyangkut pemberdayaan masyarakat. Oleh karena itu tidak heran jika ada pandangan seperti digambarkan oleh Sulistiyani \& Rosidah (2003:224), bahwa 
aparat sebagai birokrasi Indonesia yang pada umumnya masih di pandang memiliki banyak kekurangan, antara lain keengganan melayani masyarakat biasa karena statusnya dianggap lebih rendah dari dirinya.

\section{Faktor Struktur Birokrasi}

Hasil penelitian menunjukkan bahwa Tim Kooordinasi Penanggulangan Kemiskinan Daerah (TKPKD), belum memiliki struktur yang menggambarkan pendelegasian tugas dan fungsi serta wewenang para implementor. Dalam arti bahwa struktur organisasi tidak disesuaikan dengan kebutuhan program pengentasan kemiskinan. Kebijakan pengentasan kemiskinan berbasis pemberdayaan merupakan program besar pemerintah yang harus mendapatkan dukungan srtuktur organisasi birokrasi yang kuat dan terkoordinasi dengan baik dalam satu wadah sehingga mencapai sasaran serta tujuan yang diharapkan.

Menurut Lineberry dalam Putra, 2003:82, setiap implementasi melibatkan badan-badan pelaksana yang berkompeten dengan peraturan atau undang-undang yang dijadikan acuan untuk melaksanakan program tersebut, dimana suatu keputusan sebagai dasar penentuan rencana. Selain itu dalam implementasi pada akhirnya terjadi suatu perbaikan-perbaikan materi kebijakan itu sendiri yang dianggap tidak dapat diterima oleh kelompok sasaran sehingga membutuhkan suatu kebijakan, demikian seterusnya antara kebijaksanaan dan implementasi berada dalam suatu kontinum yang tidak pernah putus hingga suatu tujuan tercapai dengan baik.

Aparat pemerintah desa yang langsung berhadapan dengan warga masyarakat sasaran, selalu menerima keluhan atas pelayanan yang berbelitbelit dan membutuhkan waktu lama dengan berbagai macam alasan yang klasik dalam pandangan masyarakat. Walaupun saat ini, program pemberdayaan lebih dominan dikelola oleh kelompok masyarakat (KSM) namun dalam hal memenuhi persyaratan administrasi harus berhadapan dengan aparat pemerintah baik ditingkat desa, kecamatan maupun di tingkat daerah. Hal itu disebabkan masih adanya penekanan pada hubungan antar bagian dalam struktur organisasi pemerintahan yang tidak bisa dielakkan. Struktur birokrasi yang demikian menjadi kaku, formal dan tidak efisien dan efektif sehingga menghambat kelancaran pelayanan publik dan pada gilirannya menghambat keberhasilan pelaksanaan program pemberdayaan masyarakat. 


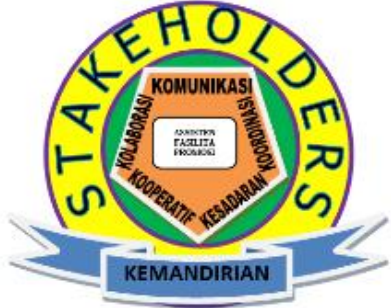

Gambar : Prototipe Mode

Pengentasan Kemiskinan Melalui Pendekatan 5-K (Five C) Di Kabupaten Pohuwato.

Berdasarkan hasil, temuan, proposisi minor dan mayor, serta merujuk pada perspektif para ahli melalui teori-teori yang menjadi landasan dalam penelitian ini, maka peneliti dapat merancang sebuah model yang menjadi novelty atau kebaruan dari penelitian ini sebagai berikut : "Keberhasilan program pengentasan kemiskinan berbasis pemberdayaan masyarakat sejatinya dilakukan melalui pendekatan 5-K (Five C) yakni : 1) komunikasi, 2) koordinasi, 3) kolaborasi, 4) kooperatif dan 5) kesadaran, sehingga tercipta kemandirian masyarakat (proaktif, kreatif, produktif, inovatif) dalam memenuhi kebutuhan dasar masyarakat (the basic needs of the community) secara berkelanjutan".

Selanjutnya dapat dideskripsikan kebaruan yang dimaksud adalah sebagai berikut :

1. Komunikasi (communication) adalah proses penyampaian informasi tentang kebijakan program pengentasan kemiskinan oleh pemerintah dan swasta kepada masyarakat sasaran yang dilakukan secara intens dalam kegiatan asisstensi, fasilitasi, dan promosi, guna meminimalisir distorsi (penyimpangan) dalam pelaksanaan program. Semakin intensif (baik) komunikasi antara pemerintah dan swasta kepada masyarakat sasaran dalam pelaksanaan program pengentasan kemiskinan melalui asistensi, fasilitasi serta promosi, akan berdampak pada kemandirian masyarakat sehingga masyarakat dapat memenuhi kebutuhan dasar (the basic need of the community) secara berkelanjutan.

2. Koordinasi (coordination) adalah suatu tindakan yang ditujukan untuk mensinkronkan dan mengatur serta mengarahkan kegiatan agar menghasilkan suatu tindakan yang seragam dan harmonis pada sasaran yang telah ditentukan. Koordinasi dimaksudkan agar pemerintah dan swasta dapat mensinergikan program-program pemberdayaan masyarakat (empowerment community) yang ada pada setiap organisasi perangkat daerah (OPD), agar tidak terjadi tumpang tindih program. Semakin berkoordinasi 
pemerintah dan swasta dengan organisasi perangkat daerah (OPD) dalam pelaksanaan program pemberdayaan masyarakat melalui kegiatan asistensi, fasilitasi serta promosi akan berdampak pada kemandirian masyarakat dalam memenuhi kebutuhan dasar masyarakat (the basic need of the community) secara berkelanjutan.

3. Kolaborasi (collaboration) adalah penciptaan hubungan kerjasama pada level pemerintah dan pada level non pemerintah, dimana pihak swasta dan masyarakat menjadi mitra penting yang turut berpartisipasi dalam program pemberdayaan yang didasari oleh komitmen dalam pencapaian tujuan. Semakin berkolaborasi dan bermitra pemerintah, swasta dan masyarakat dalam pelaksanaan program pengentasan kemiskinan melalui kegiatan asistensi, fasilitasi dan promosi, akan berdampak pada terciptanya kemandirian masyarakat (proaktif, kreatif, dan inovatif) dalam memenuhi kebutuhan dasar (the basic needs of the community) secara berkelanjutan.

4. Kooperatif (cooperation) adalah proses kerja sama, saling pengertian dan saling membantu antara stakeholders (pemerintah, swasta dan masyarakat) yang tidak menimbulkan konflik dalam pelaksanaan program pemberdayaan masyarakat. Semakin kooperatif pemerintah, swasta dan masyarakat dalam kegiatan asisstensi, fasilitasi dan promosi, akan berdampak pada terciptanya kemandirian masyarakat (proaktif, kreatif, dan inovatif) dalam memenuhi kebutuhan dasar (the basic needs) secara berkelanjutan.

5. Kesadaran (consciousness) adalah kesiagaan (awareness) pemerintah, swasta atas pelaksanaan program pemberdayaan untuk pengentasan kemiskinan. Semakin sadar/siaga Pemerintah dan swasta dalam pelaksanaan program pemberdayaan melalui kegiatan asisstensi, fasilitasi dan promosi, akan berdampak pada terciptanya kemandirian masyarakat (proaktif, kreatif, dan inovatif) dalam memenuhi kebutuhan dasar (the basic needs) secara berkelanjutan.

\section{KESIMPULAN DAN SARAN}

Berdasarkan hasil penelitian dan pembahasan tentang pengentasan kemiskinan berbasis pemberdayaan masyarakat, dapat disimpulkan sebagai berikut:

Pengentasan Kemiskinan berbasis Pemberdayaan masyarakat melalui 
Kegiatan asistensi, fasilitasi serta promosi dalam rangka memberdayakan masyarakat miskin di Kabupaten Pohuwato belum maksimal menjadikan masyarakat miskin berdaya dan mandiri yang didukung oleh kegiatan pelatihan, konsultasi dan pendampingan teknis, serta kegiatan sejenisnya serta berkolaborasi melalui koordinasi program-program yang menyulitkan fasilitator melakukan aktivitas evaluasi terhadap program-program tersebut. Faktor determinan/penentu keberhasilan pengentasan kemiskinan berbasis pemberdayaan terdiri dari faktor komunikasi, sumber daya, sikap, dan struktur birokrasi masih menjadi hambatan. Umumnya aparat di tingkat bawah (kecamatan dan desa) belum berperan aktif melalui kegiatan asistensi, fasilitasi dan promosi secara berkelanjutan (sustainability), sehingga berdampak pada meningkatnya kemandirian masyarakat miskin.

Saran dari hasil penelitian adalah sebagai berikut: Pemerintah, swasta serta stakeholders sebaiknya berperan aktif dan berinteraksi secara kolaboratif melalui kegiatan asistensi, fasilitasi dan promosi dalam mengentaskan kemiskinan berbasis pemberdayaan masyarakat di Kabupaten Pohuwato.
Pemerintah Daerah Kabupaten Pohuwato perlu mengoptimalkan kegiatan asistensi melalui kegiatan pelatihan, konsultasi dan pendampingan teknis, serta kegiatan sejenisnya lainnya yang terkoordinasi dengan programprogram penunjang. Dengan memperhatikan faktor komunikasi, sumber daya, sikap, dan struktur birokrasi, agar tidak menghambat kelancaran pelaksanaan program pengentasan kemiskinan berbasis program pemberdayaan.

\section{DAFTAR PUSTAKA}

Denhardt, Pol ert B. and Denhardt, Janet V. 2003. The New Public Service, Serving Not Steering. England: M.E Sharpe

Dunn, W. N. 2003. Pengantar Analisis Kebijakan Publik. Yogjakarta: Gadjah Mada University Press Jamasy, Owin., 2004, Keadilan, Pemberdayaan, \& Penangguiangan Kemiskinan, Bandung : Blantika

Keban, Yeremias T,2004, Enam Dimensi Strategis Administrasi Negara, Konsep, Teori dan Isu, Edisi Pertama, Cetakan Pertama, Yogyakarta : Gava Media - 2008, Enam Dimensi Strategis Administrasi Publik : Konsep, Teori dan Isu, Edisi 2, Cetakan Pertama, Yogyakarta : Gava Media. 
Kooiman, Jan (ed). 1993. Modern

Governance: New Govemment

Society Interactions, London: Sage

Publications

Kuncoro, Mudrajad, dkk.,2004,

Manajemen

Pengentasan

Kemiskinan dalam Mengelola

Dinamika Politik dan Sumberdaya

Daerah, Cetakan Kedua, Yogyakarta

: Proram S2 Politik Lokal dan

Otonomi Daerah UGM

Mafruhah, Izza.2009. Multidimensi

Kemiskinan. Surakarta : LPP UNS

Miles, MB dan AM Huberman. 2014.

Analisis Data Kualitatif: Buku

Sumber Tentang Metode-Metode

Baru, Edisi Terjemahan, Penerbit (UI

-Fress) 2014.

Osboner, David dan Peter Plastrik, 2000,

Memangkas Birokrasi (penerjemah :

Abdul Rosyid), Jakarta, PPM

Rahmaddin,MY,2009,

Perencanaan

Strategis ((Strategic Planning),

Website Ovalhanif, Makassar :

Unhas, Bandung : STKS, Jakarta : IIP

Shafritz, Jay M. and E.W. Russel. 2005.

"Introducing

Public

Administration", Fourth Edition.

Pearson Longman. New York

Sjafrizal.,2009, Teknik Praktis

Penyusunan Perencanaan

Pemerintah Daerah, Cetakan

Pertama, Padang : Baduose Media
Subarsono A.G. 2005. Analisis Kebijakan

Publik. Cetakan Pertama,

Yogyakarta: Pustaka Pelajar

Sugiyono.2005. Memahami Metode

Penelitian Kualitati. Cetakan

Kesatu, Bandung : Alfabeta

Thoha, Miftah. 2005. Dimensi-Dimensi

Prima Ilmu Administrasi Negara, Jakarta: PT RajaGrafindo Perkasa

\section{Dokumen Lain:}

Undang-Undang Nomor 23 Tahun 2014, tentang Pemerintahan Daerah

UNDP (UNESCO).1999. Declaration on Science and the Use of Scientific Knowledge, Science for the TwentyFirst Century, Budapest, Hungary, Jue 26 - July 1, 1999 pada http://www.unesco.org/science/w cs/eng/declaration/e.htm

Perpres RI. No 54 Tahun 2005, tentang Percepatan

Program

Penanggulangan Kemiskinan.

Surat Keputusan Menteri Koordinator Bid. Kesra No.25 Tahun 2007, Tentan Pedoman Umum PNPMMandiri 